見解のもとに治療をす寸めることになるが，その判断は 医師によって当然異なるものがありうるわけで，ここに も意見交換の意義が見出される。

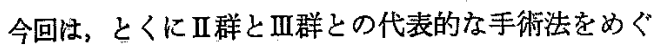
って, その術式, 実施上の注意, 術後の処置, 遠隔治㙩 成績，術前検查とその意義などについて検討しどのよ うな症例の，どのような特期にその手術が行われるべき かなどについて討議した.

なお，パネリストおよびこの闍題に関心をもたれる方 への参考として, 二つのアンケートをとり，メニエール 病の外科的治療に関する内外の現況を調查した。

国内では，全国の大学病院耳舆科教室と, 教室外の病 院に抬られる日本平衡神経科学会專門会員を対象とし， 74通のアンケートを出し，47通の回答をえた．まず手術 の実施状況については，現在または過去に経験ありとの 回答は46.8\%，機会があれば今後行いたいとの答が36.2 \%でかなりの関心がもたれているが，一方，原則として 手術は行わないとの回答が15.0\%あった，その理由とし ては，(1)原理，目的が明確でない．(2)長期的な予後に確

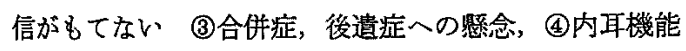
低下し固定した例の脱落症状には手術は無効, (5反復め まい発作は他の方法でコントロールできる，6適応と思 われる症例に遭遇しない. (7)手術を実施するための知 識，技術，人手などが整っていないなどの点があげられ ていた. メニエール病の全症例に対する手術例の割合る $1 \%$ 以下から20\%以上までまちまちであった，手術の術 式については, 鼓索切断, 鼓室神経鋠切除 (Rosen の手
術が30\%，ポルトマン原法あるいは変法による内リン 八ㄱ琵手術 $25 \%$ ，迷路破壊手術 $17.5 \%$, Osmotic induction method $10 \%$ ，薬物による内耳 Ablation $5 \%$ ，球形唯手 術 $5 \%$, 顽部交感神経手術，内耳涷結手術および超音波 手術がそれぞれ 2.5\%であった。

次に北米における調査は，ベイラー大学耳鼻科の五十 嵐真教授上高橋正紘博士により，米国およびカナダの耳 外科エキスパート29名にアンケートを出す方式で行われ た. 29通のアンケートに対し27通 (93.1\%) の回答があ り，すべて手術経験あり（但し現在は自分では手術を行 っていないといらもの $3.7 \%$ \%゙,メニエール病の全症例 に対する手術例の割合は $1 \sim 5 \%$ 答えたものが約半数 を占めていた，手術術式については，もっともしばしば 行う手術術式 3 点, 次が 2 点, その次が 1 点, むっとも 頻度の少ないしの0.5点として加算してみると, Surgical labyrinthectomy $61.0(39.9 \%)$, Endolymphatic shunt $23.5(15.4 \%)$, vestibular nerve section $21.0(13.7 \%)$, Endolymphatic sac decompression 17.0(11.1\%), Ultrasonic surgery $14.0(9.2 \%)$, Sacculotomy, tack operation 7.0 (4.6\%), Cryo-surgery 5.0 (3.3\%), I.abyrinth ablation by drug 4.5 (2.9\%) で, いわゆる Rosen $の$ 手術や osmotic induction method や交感神経の手術は 行われていないようであった.

国内の調查と北米のそれとは調査対象, 調查内容に相 違があり，㨁ちにこれらを比較することは適当でないと 思われるが, 討議の参考資料としてその一部を紹介し た.

めまいのみならず聴力改善を目的とした内リンパ

\title{
のう手術
}

朴 沢二郎(東北大)

\section{§1. 研究の動機及び経過}

最初, 薂物療法の研究より始めたが，めまいの治療に は患者と医師との意志の蓅通が最む重要であることを知 り，その橋渡しの場として手術的療法に兔力を感ずるよ うになった。一般にメニエール病の手術的療法には, め まい発作の消失のみを目的とし，そのため聴力を蟻牲に
するか，あるいは保存できればよいという考えが強い， しかし変動する聴力障害を特徴とする本症に扔いて，も 乙治療が適格であるならば,めまいの消失はむとより聴 力の回復む期待できる筈である.このよらな考えから現 在筆者は内リンパ整手術を行っている.この手術を行っ た症例の術前術後の聴力を比較してみると，明らかに聴 
內リンパのろ手術前

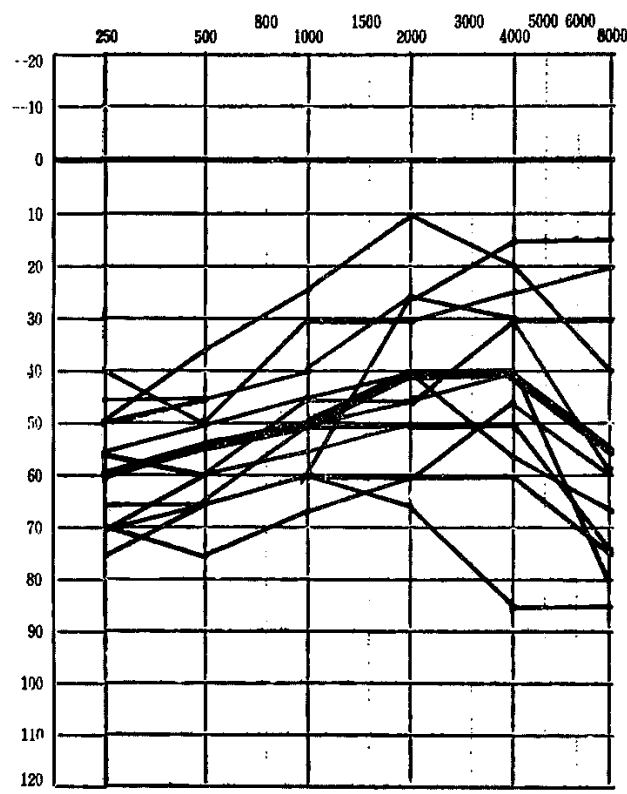

内リンパのう乎郝後

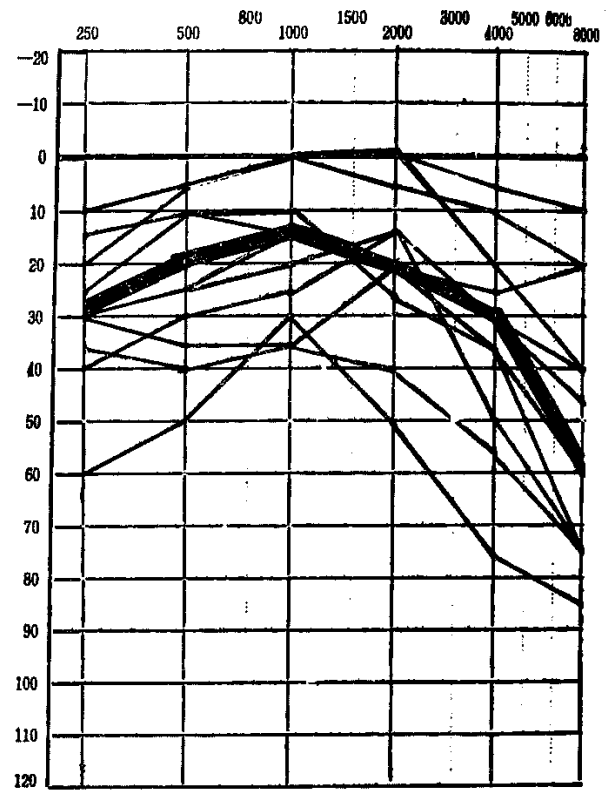

図 1 内リンパ軹手術前後の聴力の変化

左：術 前 聴 力（各症例を重称合せたもの） 右：術後 1 力月目の聴力 (

力の改善しているのが分る.（第 1 図）

\section{§2. 内リンパのう手術の適応と実施時期}

既報のように本手術はめまいに対して著しい効果があ るが, 症例によっては聴力の改善する例も経験してい る. 術前のグリセロール試験成績と術後聴力改善との関 係を15例について検討してみた 結果，両者に相関があ り，グリセロール効果の高い例ほど，術後聴力の改善が 著明であることがわかった（第 2 図）

したがってメニエール病の診断がつき，しかもグリセ ロール試験で陽性を示す例は，内リンパ綎手術の第 1 の 適応となり得る.ここで注意すべき点は, グリセロール 効果の判定法である. 私は Klockhoff の判定法とは異な った次のような式を用いて効果を算定している.

〔アミラック（内服用グリセリン）

服用前聴力 $]-[3$ 時間後聴力] $=$ ジリセロール効果 服用前聴力

この判定によれば，服用前の聴力障害の高度のむので はグリセリン服用後，かなり著明な聴力改善を見ない 限りグリセロール効果陽性とならない，逆に聴力障害 の軽いものではグリセロール効果が陽性になり易いので

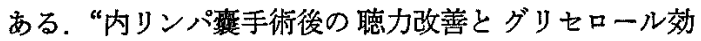

果とは必ずしも平行しない”という報告もあるが，それ は採用しているグリセロール効果の判定法に問題がある 訳である。 また，“聴力障害の軽い例では術後聴力改善 のみられる場合が多い”といら従来の報告を私のグリセ ロール効果算定法加らも証明することか゚できる. 一方め

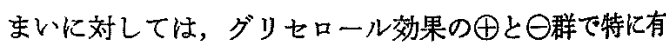
意の差はなく，何れにも有効であった。また手術を何時 行うべきかという問題であるが，私はメニエール病の確 定診断がついたら，直ぐ行うべきと考える，しかし周辺 疾患との鑑別，特に経過観察に意外に時間を費やしてお り，私の手術を行った例は 1 年以上が大半であった. 私 としてはもっと早期に手術を行いたい希望を持ってい る。

\section{§3. 手術実施上の注意}

内リンパ霆手術には大きく分けて，外側壁切開法と内 側壁初開法の二つあるが, 聴力改善の目的からは内リン パ露外側壁切開法の方が望ましい，非常にまれで仿る が，私は術後ほとんどろうになった例を2 例経験してい る.この例は内リンパ垔内側壁を破り，術後 Liquorthoe が長く続いた例である。私は切開口から血液あるい法抗 生剤が逆行して螖牛に達し聴力障害を超したのではな 
グリセロール効果と術後聴力改善との関係

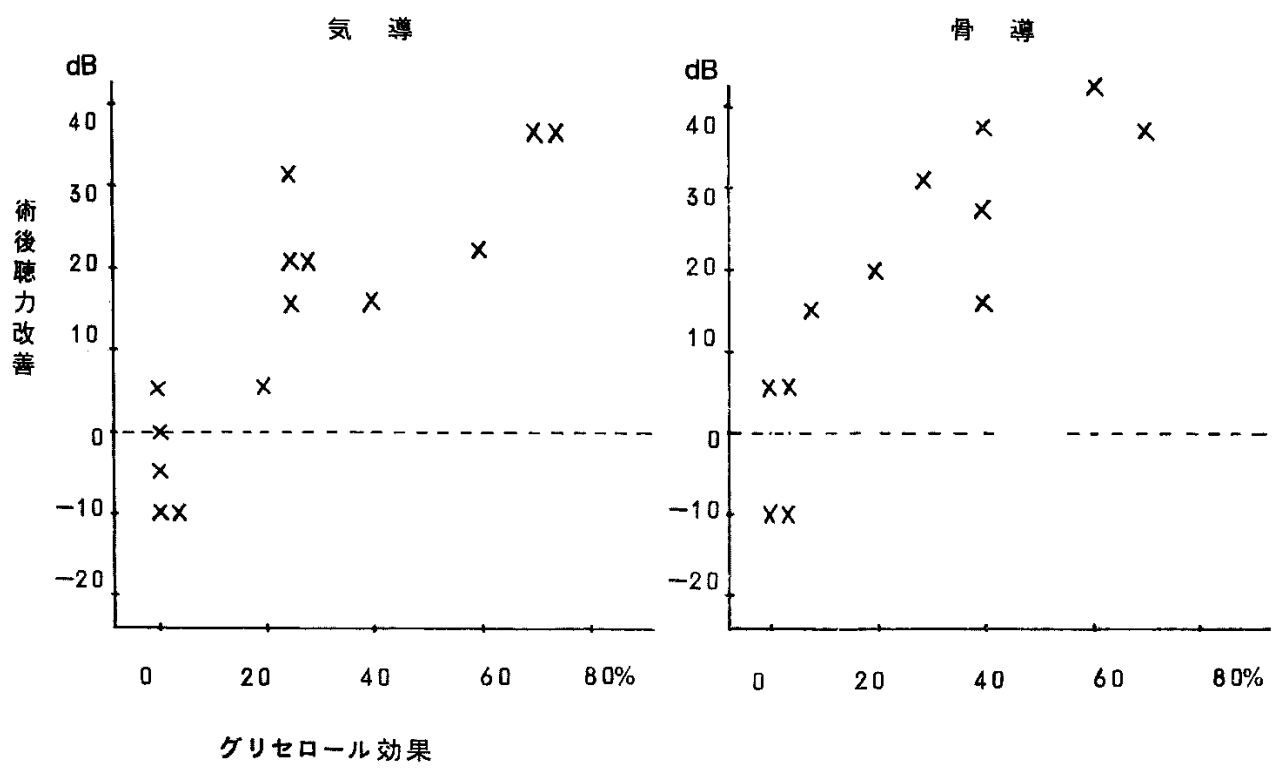

図 2 グリセロール効果と聴力改善との関係

横軸 : グリセロール効果 (\%)

$\underline{\text { (アミラック投与前聴力)一(投与後聴力) }} \times 100 \%$

预軸：術後聴力改善 $(\mathrm{dB})$ (投与前聴力)

術前㯖力 $\left(\frac{250+500+1000 \mathrm{~Hz}}{3}\right)-$ 術後聴力 $\left(\frac{250+500+1000 \mathrm{~Hz}}{3}\right)$

（注意）グリセロール効果の判定は Klockhoff 法と異なりグリセリンによる聴力改善を服用前の聴力で割 ったものを百分率で表わしている。したがって服用前聴力障害の高度なものはグリセリン服用後か なり聴力改善がみられない限り，グリセロール効果陽性とならないことに注目されたい

がとの危具を抱き，金子博士等の協力を得て動物実験を 行ってみた，その結果，切開口よりカーボン粒子の侵入 は見られず，本手術の安全度の高いことが再碓認され た.

\section{§4. まとめ}

内リンパ襄手街はメニエール病の外科的療法の中で最 も合理的な手術であり，その正当性は戦後立木名誉教授 が手街された長期観察例の成績によって実証されてい る. しかしここで注意して頂きたいことは，内リンパ整 手術はめまい発作の原因的治療ではなく, 内リンパ水腫 に対する減圧効果により内耳機能の改善をはかるもので
ある、したがって症例によっては術後む発作の原因に相 遇すれば，めまいを起す可能性がある．私はメニエール 病の治療に必要なものとして次の 5 項目を考えている.

1）周辺疾患との鑑別

2) 病状の客観的把握

3）医師と患者との意志の疏通

4）內まい発作を阻止し，内耳機能改善をはかる手術 法の实施と薬物療法との調和.

5）術後健康管理と社会復䏒のための生活指導その中 で，内リンパ褧手術の存在意義は大きいと思う。 